\title{
KETERBUKAAN INFORMASI PUBLIK DATA PERTANAHAN
}

\author{
Nur Rahmanto
}

\author{
Sekolah Tinggi Pertanahan Nasional \\ Jl. Tata Bumi No. 5 Banyuraden, Gamping, Yogyakarta \\ Corresponding author: Nur_rahmanto@stpn.ac.id
}

\author{
Vol 1, No. 1 \\ April 2021 \\ Received \\ May $03^{\text {rd }} 2021$ \\ Accepted \\ May $26^{\text {th }} 2021$
}

\begin{abstract}
In essence, every citizen has the right to know about all activities or policies carried out by public officials, this is in addition to the right to obtain information, it is a human right as well as a means of public control over government administration, but the right to obtain this information is often There are obstacles both in terms of regulations and unsupportive behavior of public officials. Law Number 14 of 2008 (UU KIP) which regulates the issue of public information disclosure in its implementation conflicts with Permenagraria / Ka BPN Number 3 of 1997, in which the regulation of the Minister of State for Agrarian Affairs regulates restrictions on restrictions in providing information on land data which are often inconsistent with with the regulation of public information disclosure regulated in the KIP Law, so that the public does not immediately get information on land data which in turn will lead to a lawsuit from the public to the Ministry of Agrarian Affairs and Spatial Planning / BPN at the Information Commission and State Administrative Court. By using the desk study method, this paper will examine the information disclosure arrangements stipulated in the two regulations referred to as well as the conflicts that occur both in the articles of the contents of the regulations and in their implementation practices so that solutions or recommendations will be obtained so that public information disclosure can run properly in Indonesia country.
\end{abstract}

Keywords: public information disclosure, data sharing, land data

\section{INTISARI}

Setiap warga masyarakat pada hahekatnya adalah berhak untuk tahu mengenai semua kegiatan atau kebijakan yang dilakukan oleh pejabat publik, hal ini selain hak untuk memperoleh informasi itu adalah hak asasi setiap manusia juga sebagai sarana kontrol publik terhadap penyelenggaraan pemerintahan, akan tetapi hak untuk memperoleh informasi ini sering ada kendala baik dari sisi regulasi maupun perilaku petugas publik yang tidak mendukung. Undang Undang Nomor 14 Tahun 2008 (UU KIP) yang mengatur masalah keterbukaan informasi publik dalam pelaksanannya berbenturan dengan Permenagraria/Ka BPN Nomor 3 Tahun 1997, dimana di dalam peraturan Menteri Negara Agraria dimaksud diatur mengenai pembatasan pembatasan dalam memberikan informasi data pertanahan yang seringkali tidak sejalan dengan pengaturan keterbukaan informasi publik yang diatur di dalam UU KIP, sehingga masyarakat tidak serta merta bisa mendapatkan informasi data pertanahan yang pada akhirnya akan memunculkan gugatan dari masyarakat kepada Kementerian Agraria dan Tata Ruang/BPN di Komisi Informasi dan Pengadilan Tata Usaha Negara. Dengan menggunakan methode desk study tulisan ini akan mengkaji pengaturan keterbukaan informasi yang diatur di dalam kedua peraturan dimaksud serta pertentangan yang terjadi baik di dalam pasal pasal isi peraturan maupun di dalam praktek pelaksanaannya untuk selanjutnya akan diperoleh solusi atau rekomendasi sehingga keterbukaan informasi publik dapat berjalan dengan baik di Negara Indonesia.

Kata Kunci: keterbukaan informasi publik, berbagi data, data pertanahan.

\section{A. Pendahuluan}

The right to know "hak untuk tahu" merupakan hak konstitusional setiap warga negara untuk mendapatkan informasi telah ditegaskan dalam Pasal 28 huruf F UUD 1945 yang menyatakan bahwa: "Setiap orang berhak untuk berkomunikasi dan 
memperoleh Informasi untuk mengembangkan pribadi dan lingkungan sosialnya, serta berhak untuk mencari, memperoleh, memiliki, dan menyimpan informasi dengan menggunakan segala jenis saluran yang tersedia". Berdasarkan peraturan tersebut maka setiap orang berhak untuk mendapatkan informasi yang dikelola oleh badan publik penyelenggara Negara dan hak tersebut mutlak dijamin sebagai bagian dari hak asasi manusia (Asshiddiqi, 2005). PBBpun juga menyatakan hak ini sebagai hak dasar manusia yang tercantum dalam Deklarasi Universal Hak Asasi Manusia.

Semakin mudah seorang warga negara mendapatkan informasi publik maka semakin baik pula pemerintahan negara tersebut. Hal ini menunjukkan adanya korelasi antara keterbukaan informasi dan kualitas pemerintahan. Dwiyanto (2008) menyebutkan bahwa keterbukaan informasi merupakan salah satu perwujudan dari usaha untuk melaksanakan pemerintahan yang baik. Dengan lebih terbukanya akses publik terhadap informasi maka akan lebih mendorong badan-badan publik untuk melaksanakan tugasnya dengan baik dan bertanggung jawab, sehingga akan tercipta pemerintahan yang baik (Good Governance). Selain pemerintahan yang baik, adanya keterbukaan informasi ini diharapkan memunculkan pula partisipasi masyarakat untuk mengontrol jalannya pemerintahan. Dari gambaran kondisi tersebut maka dapat dikatakan bahwa informasi merupakan hal yang tidak bisa dipisahkan dari kehidupan suatu Bangsa (Nasucha dan Moenawar, 2020).

Ditinjau dari penerapannya, terdapat 79 negara yang telah menerapkan peraturan perundangan mengenai hak untuk tahu bagi setiap warga negaranya. Indonesia merupakan negara urutan kelima di Asia setelah Nepal, Thailand, India, dan Jepang (Lutfi dan Satriawan, 2013). Di Indonesia, pengaturan jaminan hak atas informasi diatur dalam Undang-Undang Nomor 14 Tahun 2008 tentang Keterbukaan Informasi Publik atau disebut sebagai UU KIP. Dengan disahkannya undang-undang ini maka setiap warga negara dapat mengetahui dan mengakses setiap layanan publik, dan secara tidak langsung dapat memantau setiap kebijakan badan publik penyelenggara pemerintahan. Ketika semua informasi telah dapat diakses oleh publik maka setiap langkah badan publik dapat dipertanggungjawabkan kembali kepada masyarakat (akuntabel), yang pada akhirnya terwujudlah penyelenggaraan negara yang baik dan transparan (Mandica-Nur, 2009; Suryani, 2017).

Walaupun keterbukaan publik telah diatur dalam UU KIP, belum semua lembaga mampu melaksanakannya (Febrianingsih, 2012). Contoh pertama yaitu di Kota Malang, permasalahan mengenai anggaran, sumber daya manusia dan sarana prasarana menjadi kendala bagi Pemerintah Kota Malang dalam melaksanakan keterbukaan informasi publik walaupun telah memiliki rujukan Pedoman Pelayanan Informasi Publik (Putro, 2014). Di tempat lain, tepatnya di Kabupaten Kepulauan Meranti, Pejabat Pengelola Informasi dan Dokumentasi (PPID) telah berjalan sesuai ketentuan walaupun terdapat sejumlah faktor penghambat dalam pelaksanaan kebijakan keterbukaan informasi publik seperti faktor sumber daya (manusia dan anggaran), faktor disposisi, dan faktor struktur birokrasi (Astuti, 2016). Tujuan dari kajian ini adalah untuk mengetahui penerapan keterbukaan informasi bagi publik di ATR/BPN. Hal inilah yang membedakan kajian ini terhadap kajian terdahulu yaitu 
terletak pada implementasi UU KIP dengan Permenagraria/Ka.BPN Nomor 3 Tahun 1997, khususnya pasal-pasal yang mengatur mengenai pemberian informasi berupa data pertanahan oleh satuan kerja di Kementerian ATR/BPN kepada masyarakat.

\section{B. Metode penelitian}

Kajian di penulisan ini menggunakan metode desk study yaitu dengan mempelajari data-data sekunder, kajian-kajian terdahulu, serta peraturanperaturan perundangan yang mendukung dan berkaitan dengan tema keterbukaan informasi publik. Sejumlah sumber data dan literatur tersebut dianalisis kemudian dideskriptifkan sesuai dengan kondisi di ATR/BPN.

\section{Regulasi dan praktek keterbukaan informasi public}

Di dalam pasal 1 angka 2 UU Nomor 28 Tahun 1999 disebutkan bahwa informasi publik adalah informasi yang dihasilkan, disimpan, dikelola, dikirim, dan/atau diterima oleh suatu badan publik yang berkaitan dengan penyelenggara dan penyelenggaraan negara dan/atau penyelenggara dan penyelenggaraan badan publik lainnya yang sesuai dengan Undang-Undang ini serta informasi lain yang berkaitan dengan kepentingan publik. Di pasal yang lain, keterbukaan didefinisikan sebagai asas yang membuka diri terhadap hak masyarakat untuk memperoleh informasi yang benar, jujur dan tidak diskriminatif tentang penyelenggaraan negara dengan tetap memperhatikan perlindungan atas hak asasi pribadi, golongan, dan rahasia negara. Berdasarkan pengertian tersebut, Baskoro dkk (2020) mengungkapkan bahwa informasi merupakan milik publik dan bukan milik pemerintah atau badan publik.

Apabila merujuk pada Pasal 3 UU KIP maka undang-undang ini bertujuan untuk: (1) menjamin hak warga negara untuk mengetahui rencana pembuatan kebijakan publik, program kebijakan publik, dan proses pengambilan keputusan publik, serta alasan pengambilan suatu keputusan publik; (2) mendorong partisipasi masyarakat dalam proses pengambilan kebijakan publik; (3) meningkatkan peran aktif masyarakat dalam pengambilan kebijakan publik dan pengelolaan Badan Publik yang baik; (4) mewujudkan penyelenggaraan negara yang baik, yaitu yang transparan, efektif dan efisien, akuntabel serta dapat dipertanggungjawabkan; (5) mengetahui alasan kebijakan publik yang mempengaruhi hajat hidup orang banyak; (6) mengembangkan ilmu pengetahuan dan mencerdaskan kehidupan bangsa; (7) meningkatkan pengelolaan dan pelayanan informasi di lingkungan Badan Publik untuk menghasilkan layanan informasi yang berkualitas. Dengan demikian dapat dikatakan bahwa hak untuk memperoleh informasi ini adalah termasuk hak asasi manusia sehingga hak asasi ini menjadi asas undang undang (Mujiburohman, 2017).

Disamping informasi yang wajib disediakan, di dalam pasal 2 UU KIP diatur pula mengenai pembatasan informasi, bahwa informasi dikecualikan bagi publik apabila bersifat rahasia menurut Undang-Undang, terdapat konsekuensi yang timbul apabila diberikan kepada masyarakat, serta dapat melindungi kepentingan yang lebih besar. Pasal 2 tersebut dipertegas kembali di Pasal 6 UU KIP yang menyatakan 
bahwa badan publik berhak menolak memberikan informasi publik apabila tidak sesuai dengan ketentuan peraturan perundang-undangan. Informasi yang dikecualikan tersebut antara lain: (1) informasi yang apabila dibuka dan diberikan kepada pemohon informasi dapat menghambat proses penegakan hukum, yaitu informasi yang dapat menghambat proses penyelidikan dan penyidikan suatu tindak pidana; (2) mengungkapkan identitas informan, pelapor, saksi, dan/atau korban yang mengetahui adanya tindak pidana; (3) mengungkapkan data intelijen kriminal dan rencana-rencana yang berhubungan dengan pencegahan dan penanganan segala bentuk kejahatan transaksional; (4) membahayakan keselamatan dan kehidupan penegak hukum dan/atau keluarganya; (5) membahayakan keamanan peralatan, sarana, dan/atau prasarana penegak hukum.

Pengecualian atau pembatasan informasi bagi publik selain diatur dalam pasal 17 UU KIP juga diatur dalam UUD Tahun 1945 pada Pasal 28 huruf J. Di dalam UUD tersebut disebutkan bahwa pembatasan dimaksudkan semata-mata untuk menjamin pengakuan serta penghormatan atas hak dan kebebasan orang lain dan untuk memenuhi tuntutan yang adil sesuai dengan pertimbangan moral, nilai-nilai agama, keamanan dan ketertiban umum dalam suatu masyarakat demokratis. Hal inilah yang menjadi dasar bahwa merupakan kewajaran apabila ada pembatasan keterbukaan informasi publik atau ada informasi yang tidak dapat diberikan kepada masyarakat.

Di tataran praktek terdapat perbedaan tafsir terhadap informasi yang dikecualikan ini di lingkungan BPN. Di lingkungan BPN, perbedaan tafsir terjadi karena terdapat aturan menyebutkan data yang bersifat terbuka untuk umum namun di aturan lain terdapat pembatasan data. Di dalam Peraturan Kepala BPN Nomor 3 Tahun 1997 yang merupakan ketentuan pelaksana dari Peraturan Pemerintah Nomor 24 Tahun 1997, pada Pasal 1 angka 12 disebutkan bahwa warkah merupakan alat pembuktian data fisik dan data yuridis bidang tanah yang telah dipergunakan sebagai dasar pendaftaran bidang tanah tersebut dan pada Pasal 187 ayat (1) disebutkan bahwa data fisik dan data yuridis terbuka untuk umum. Namun kemudian pengertian terbuka untuk umum ini dibatasi oleh: (1) Pasal 197 ayat (2) yang mengatur bahwa data yuridis dan data fisik tersebut diberikan dalam bentuk Surat Keterangan Pendaftaran Tanah dan bukan dalam bentuk Salinan atau fotocopy warkah; (2) Pasal 188 ayat (2) yang mengatur bahwa Salinan atau fotocopy peta hanya dapat diberikan kepada pemegang hak saja; dan (3) Pasal 191 ayat (1) yang mengatur bahwa data fisik dan data yuridis hanya dapat diberikan kepada Instansi Pemerintah yang memerlukan untuk keperluan melaksanakan tugasnya.

Adanya perbedaan pengaturan di lingkup BPN kemudian dianggap oleh masyarakat, yang bukan pemegang hak dan bukan instansi pemerintah yang memerlukan data pendaftaran tanah, merasa kesulitan mendapatkan data pertanahan. Keadaan inilah selanjutnya muncul pengaduan dari masyarakat ke Komisi Informasi (KI). Kendati terdapat sejumlah aduan, Kementerian ATR/BPN mendapatkan nilai 74,67 dan dikategorikan sebagai badan publik yang cukup 
informatif berdasarkan kegiatan Monitoring dan Evaluasi Keterbukaan Informasi yang dilakukan oleh Komisi Informasi Pusat tahun 2019.

\section{Kesimpulan}

UU KIP hadir untuk mendorong terciptanya proses demokratisasi dalam penyelenggaraan pemerintahan sehingga masyarakat bisa mengetahui setiap bentuk layanan publik yang mereka terima sekaligus juga sebagai bentuk peran aktif masyarakat memantau setiap gerak langkah badan publik yang berkaitan kebijakan penyelenggaraan pemerintahan. Dalam implementasinya pengaturan mengenai hak untuk memperoleh informasi dalam UU KIP ini berbenturan dengan kepentingan dari Kementerian ATR/BPN untuk menjaga kerahasiaan data sebagaimana diatur di dalam Peraturan Pemerintah Nomor 24 Tahun 1997 yang diatur lebih lanjut didalam Peraturan Kepala BPN Nomor 3 Tahun 1997. Di sisi lain, di internal BPN sendiri masih terdapat perbedaan pengaturan mengenai informasi yang terbuka dan terbatas. Sepanjang tidak ada kejelasan aturan maka akan mengganggu kegiatan pelayanan kepada masyarakat.

\section{E. Rekomendasi}

Untuk menghindari kebingungan baik di pihak masyarakat maupun petugas pelaksana di Kementerian ATR/BPN maka solusi yang sebaiknya dilakukan adalah :

1. Pihak Kementerian ATR/BPN melaksanakan secara penuh ketentuan yang diatur di dalam UU KIP dalam memberikan informasi data pertanahan yang diminta oleh masyarakat, sepanjang memang bukan informasi yang dikecualikan.

2. Dalam hal informasi mengenai data pertanahan tertentu dianggap sensitif untuk diberikan kepada masyarakat oleh Kementerian ATR/BPN, dan itu bukan merupakan informasi yang dikecualikan (vide Pasal 2 ayat 4 UU KIP), maka sebaiknya keterbukaan informasi data pertanahan diatur tersendiri dalam sebuah peraturan setingkat Peraturan Pemerintah yang merupakan peraturan pelaksanaan dari UU KIP.

\section{Daftar Pustaka}

Asshiddiqie, J. (2005). Hukum Tata Negara dan Pilar-Pilar Demokrasi. Jakarta: Konstitusi Press.

Astuti, H. (2016). Implementasi Keterbukaan Publik (KIP) di Kabupaten Kepulauan Meranti Tahun 2011-2015, JOM FISIP, 3(2), 1-10.

Budiarjo, M. (1993). Dasar Dasar Ilmu Politik. Jakarta: PT. Gramedia Pustaka Utama.

Debora, A. (2016, Maret). Status Informasi Pertanahan Di Rezim Keterbukaan Informasi. FGD Informasi Publik pada Dokumen Pertanahan yang diselenggarakan oleh Komisi Informasi Pusat. Diakses dari https://icel.or.id/wp-content/uploads/Status-Informasi-Pertanahan-di- 
Rezim-Keterbukaan-Informasi.pdf.

Departemen Pendidikan Nasional. (2008). Kamus Besar Bahasa Indonesia. Jakarta:

PT. Gramedia Pustaka Utama.

Dwiyanto, A. (2008). Mewujudkan Good Governance Melalui Pelayanan Publik. Yogyakarta: Gajah Mada University Press.

Febrianingsih, N. (2012). Keterbukaan Informasi Publik Dalam Pemerintahan Terbuka Menuju Tata Pemerintahan Yang Baik. Jurnal RechtsVinding, 1(1), 135-156.

Komisi Informasi Pusat. (2020, April). Laporan Tahunan Komisi Informasi Pusat Tahun 2019. Diakses tanggal 10 April 2021 dari https://komisiinformasi.go.id/?portfolio=laporan-tahunan-komisiinformasi-pusat-tahun-2019.

Lutfi, M., \& Satriawan, M.I. (2013). Meneropong Komisi Informasi Publik. Malang: Universitas Brawijaya Press (UB Press).

Mertokusumo, S. (2001). Penemuan Hukum Sebuah Pengantar. Yogyakarta: Liberty. Mujiburohman, D.A. (2017). Pengantar Hukum Tata Negara. Yogyakarta: STPN Press.

Nasucha, M., \& Moenawar, M.G. (2020). Covid-19, Asimetri dan Keterbukaan Publik. Dalam D.H. Santoso, Nurudin, \& F. Junaedi (Eds.), Media, Komunikasi dan Informasi di Masa Pandemi Covid-19 (pp. 74-93). BridgePress.

Nur, M. (2009). Panduan Keterbukaan Informasi Publik (KIP) Untuk Petugas Pengelola dan Pemberi Informasi Publik di Badan Publik. Jakarta: Depkominfo, IRDI, dan USAID.

Prasetyo, P.K., Christine, R.V., \& Sudibyanung. (2020). Implementasi Asas Keterbukaan Pada Pengadaan Tanah Bagi Pembangunan Untuk Kepentingan Umum: Antara harapan dan Kenyataan. BHUMI: Jurnal Agraria dan Pertanahan, 6(1), 15-27.

Puspitosari, H., Khalikussabir, Kurniawan, L.J., Lutfi, M. (2011). Filosofi Pelayanan Publik. Malang: Setara Press.

Putro, B.S.W. (2014). Peran PPID Dalam Pelayanan Serta Penyediaan Informasi Publik (Skripsi S1). Universitas Brawijaya. Malang.

Rasjid, M.R. (1998). Desentralisasi Dalam Menunjang Pembangunan Daerah Dalam Pembangunan Administrasi di Indonesia. Jakarta: Pustaka LP3ES.

Sugiyono. (2015). Metode Penelitian Pendidikan, Pendekatan Kuantitatif, Kualitatif dan R\&D. Bandung: Alfabeta.

Sumardjono, M.S.W. (2007). Kebijakan Pertanahan antara Regulasi dan Implementasi. Jakarta: Penerbit Kompas.

Sumartias, S. (2016). Dinamika Keterbukaan Informasi Publik. Jakarta: Penerbit PT. Balai Pustaka.

Suryani, A.D. (2017). Mewujudkan Good Governance Publik Negara di Daerah Istimewa Yogyakarta Melalui Keterbukaan Publik. Spirit Publik, 12(1), 35-44.

Zulkarnain, S., \& Widiarto, A.E. (2006) Menggagas Keterbukaan Informasi Publik Upaya Kolektif Berantas Korupsi. Malang: In Trans Publishing. 
Pemerintah Republik Indonesia. (2008). Undang-Undang Nomor 14 Tahun 2008 Tentang Keterbukaan Informasi Publik.

Pemerintah Republik Indonesia. (2014). Undang-Undang Nomor 30 Tahun 2014 tentang Administrasi Pemerintahan.

Pemerintah Republik Indonesia. Peraturan Pemerintah Nomor 24 Tahun 1997 tentang Pendaftaran Tanah.

Badan Pertanahan Nasional. (1997). Peraturan Menteri Negara Agraria/Kepala BPN Nomor 3 Tahun 1997 tentang peraturan pelaksanaan Peraturan Pememerintah Nomor 24 Tahun 1997 tentang Pendaftaran Tanah. 